

Renata Klufová

Department of Applied Mathematics and Informatics, Faculty of Economics, University of South Bohemia in České Budějovice

\title{
Current Delimitation and Typology of the Czech Countryside and its Importance for Rural Development
}

\begin{abstract}
The aim of the paper is to delimit the countryside in the Czech Republic (according to local conditions) and the rural municipalities' typology (according to their development potential). The author also focuses on the usage of a combination of Geographic Information Systems, spatial data analysis, and spatial statistics tools, together with traditional multivariate statistical methods for rural delimitation and typology. The typology of the rural municipalities, according to their development potential, is based on up-to-date socio-economic indicators from the 2011 Census, which makes up the final part of the article, followed by conclusions and considerations about future rural development in the Czech Republic.
\end{abstract}

Keywords: rural delimitation, rural typology, GIS, LISA analysis, multivariate statistical methods 


\section{Introduction}

The countryside and its problems and delimitation have been described in many items of literature and there are lots of authors and institutions devoted to this topic for both theoretical and scientific or practical reasons (e.g. delimitation of the countryside due to targets of different development programmes), e.g. Short (1991), Kubeš (2000), Novotná (2000), Perlín (2008, 2013), Woods (2011), and lots of others.

Rural settlements themselves are of a different character as well. They may be hamlets, small settlements or quite large villages, of which some may have a larger population than towns. Villages in the surroundings of larger towns are a typical example, where we meet, thanks to processes of suburbanisation, lots of signs typical of towns (see, for example, Ouředníček et al. 2013b). Due to differences in definitions of the rural and town areas, it is difficult to delimit the terms "rural settlements" and "town settlements" clearly.

In recent decades there has been approved a significant movement in the conceptofassessmentandmanagement of theruralchanges from technological, managerial and centralised attitudes to more constructive, participative and decentralised ones focussed on the development of the countryside (Ellis 2001). One of the most significant items of restructuralisation of the rural areas is the transition from economics based on agricultural production to economics using the countryside as a commodity. Woods (2011: 93-95) even speaks about a concept of commodification.

A new rural paradigm (OECD 2006) closely associated with the territorial approach is currently being discussed. According to this theory, there are no predefined borders for the territory (neither administrative nor physical), but the origin of it is created by the aggregation of groups of people with the same problems or opportunities. Territory in this meaning represents a system which integrates various endogenous sources and their interrelationships. That is why a structural change may potentially be started by any member of this system. According to Ambrosio-Albalá and Bastiansen (2010), rural territory is not defined as a physical support of activities done by people, but by an independent actor, a live organism created by cells in an interrelationship (acting with one another) - individualities, households, etc.

Tourism plays a special role in economic activities in the countryside because of its potential for the regeneration of rural areas, the creation 
of corporate investments in the private, public and voluntary sectors (Garrod et al. 2006), and to help farmers to make up their incomes (Ambrosio-Albalá, Bastiansen 2010). Economic diversification has been supposed as the first step towards increasing agriculturally productive systems (Evans 2009). Sustainable usage of natural sources has become a popular alternative of the countryside transformation. Other non-agricultural activities should provide new possibilities for local employment. Public interventions play a certain role as well, e.g. granting certification to some products can bridge the gap in protection and regulation of local source usage ( $\operatorname{Sanz} 2005$ ). A new rural paradigm also takes into account "non-commodities" such as landscape, natural heritage, environment and culture as potential sources of the rural economic transformation (Ambrosio-Albalá, Bastiansen 2010; Woods 2011).

An explicit delimitation of the countryside is not possible - different combinations of quantitative or qualitative indicators result in various outputs. There are two different ways to approach problems of delimitation of rural space. We can see the countryside as a coherent territory consisting of a free landscape and individual settlements, and then it is delimited by indicators related to the area (density of population). Rural space is also possible to delimit as a set of rural municipalities. In this meaning the rural municipality is thought of as a discontinuous delimitation of individual settlements, municipalities according to stated criteria, which are related to a unit, and then we mean absolute indicators (number of inhabitants, administration function, etc.). It is worth observing whether the continuum of settlements' dimension or their exposition is often discussed.

\section{Material and Methods}

\section{Delimitation of the Countryside}

The proposal from the working group for the Plan of the Rural Development 2014-2020, following the differentiation based on the delimitation of the Strategy of Regional Development in the Czech Republic in 2014-2020 (Perlín 2013), is the basic material of this article. According to the proposal, villages within the limit of up to 3,000 inhabitants, situated in stabilised or peripheral areas within the Strategy of Regional Development in the Czech Republic in 2014-2020 (2013: 56), should be included among rural municipalities. 
For the analytical purpose of this paper, villages of up to 3,000 inhabitants, situated outside the commuting zones of core towns with more than 10,000 inhabitants, and delimited primarily on transport access modelled in the program ArcGIS via Network Analyst extension, were included among the rural municipalities.

\section{Typology of Rural Municipalities}

Together with changes of relative geographical location, deeper municipality differentiation, and hierarchisation (Hampl 1998; Perlín et al. 2010), all rural areas differentiate. The differences are obvious both in population structure and in activities which are carried out in rural municipalities. Therefore, different development prerequisites exist in particular municipalities. The typology of the municipalities results from the fact that a development potential projects into selected socio-economic indicators (Perlín et al. 2010). For that reason, the analysis is based on the data sources available from the last census concerning the structure of rural population at the level of municipalities, local facilities, employment, location, size, and other characteristics. The analysis also contains the indicators which, in some way, depict the quality of social and human capital of rural municipalities. We supposed that the final typology could be identical to that of similar rural types of typology made by Perlín et al. (2010), even though it is realised at the level of Administrative Districts of Municipalities with Authorized Local Authority with the use of different indicators and methods.

Here we followed current approaches to regional development, which result from institutional theories. They understand the support of local entrepreneurship as the developmental prerequisite and emphasise the use of local conditions and developmental prerequisites (see, for example, Lee et al. 2005; Daskalopoulou et al. 1998; Ellis, Biggs 2001; Floysand, Jakobsen 2007; Jenkins 2000, and others). The delimitation of different types of rural areas will help to better perceive the current state and processes affecting it and the prerequisites for further development.

All characteristics mentioned above were defined by the set of variables available at the level of municipalities:

- Size and geographical location - population in 2011 (O2011), the cadastral area of the municipality (HA), the population density in 2011 (hustota11), the division of the municipality into smaller parts 
(CASTI11); geographical location - the distance from the nearest municipality with extended powers (NEARORP), the distance from the nearest railway station (NEARZS), the distance from the nearest main road (NEARHSIL). The distances mentioned above were calculated through the NEAR tool in the ArcGIS computer program;

- Agricultural production - employment in the primary sector (PRIM11r), the share of employees in the total number of employees (ZAMST11r), the share of own-account workers (OSVC11r), the share of agricultural land (ZP11r); the rate of employment (OZC11r) the share of employed population in economically active population; $\mathrm{ZMC11r}$ - the ratio of employers to the total number of employees;

- Space for recreation - employment in lodging and boarding industries (UBYT11r), number of public lodging establishments (HUZ11), the share of unoccupied houses in the total number of houses (NEOBD11r), the share of unoccupied houses used for recreation in unoccupied houses (DREKR11r), the share of water and forest areas in the total cadastral area (VODYLESY11r);

- Space for living - the share of built-up and other areas (ZAST11r), the share of family houses (RD11r), the share of houses built or reconstructed during 2001-2011 (D01_11r), the share of houses connected to sewerage (KANAL11r), the share of natives (NAROB11r); balance of migration - chronological average in 20012012 (chpMS01_12); natural increase of population - chronological average in 2001-2012 (chpPP01_12), the development index of population in 2001-2011 (IO01_11), the share of people married in the number of people over 15 (MANZ11r), the share of believers in total population (VIRA11r), the ageing index (IS11), the index of economic burden (IEZ11);

- Space for life - daily commute to work (VYJdmo11r), the education index (IVZD11).

The typology of rural municipalities itself resulted from the subset of these municipalities and only military training areas and Prague were excluded.

The first step was a correlation analysis of all suggested variables where low or medium dependences between particular variables prevail. A high value of the Pearson correlation coefficient led to excluding the variables ZP11r and OSVC11r, which seem to be redundant for the model. 
The author started with a cluster analysis of all input variables with the aim to identify clusters of related variables. The method of principal components analysis (PCA) was subsequently used in particular clusters of variables. Concurrently with ZP11r and OSVC11r, a chronological average of the crude rate of natural increase was excluded from the model, as the birth rate of the Czech population is low and affects the total population development insignificantly, which was also proven in a contribution of these variables to particular components.

Hierarchical clustering by Ward's method (see, for example, Hebák et al. 2005) identified four clusters of variables depicting particular parts of the development potential of rural municipalities, and can be generally characterised as follows:

- Importance and size of the municipality - hustota11, ZAST11r, KANAL11r, HA, O2011, CASTI11, HUZ11, UBYT11r;

- Development of the municipality - IVZD11, BDINT11r, OZC11r, ZMC11, D01_11, chpMS01_11, IO01_11;

- Potential for economic and leisure activities - IS11, IEZ11, PRIM11, NEOBD11r, DREKR11r, NEARHSIL, NEARORP, NEARZS, VODYLESY11r;

- Social stability and employment - ZAMST11r, NAROB11r, VIRA11r, VYJdmo11r, RD11r, MANZ11r.

Then, each cluster of variables was subjected to PCA to reduce the number of variables used for the typology of municipalities. For better interpretation and finding a meaningful data structure, the author also used factor analysis, in which obtained factors were found by a principal components method and subsequently rotated by the varimax method, which produces orthogonal factors and meets the requirements of the simplest structure (Harris 2001; Hebák et al. 2005).

The initial set of 29 variables, in some way characterising individual aspects of the development potential of individual municipalities, was therefore reduced to 10 factors. The values of these 10 factors were then used as input variables for cluster analysis in order to carry out a typology of rural municipalities.

Individual factors were also subjected to testing the existence of spatial autocorrelation and spatial clustering, and thus to perform a so-called LISA (Anselin 2010), which is used for the identification of spatial clusters of similar values in the case of positive spatial autocorrelation. This technique 
of spatial statistics was used in order to analyse a spatial pattern of the factors. Local spatial autocorrelation analysis (LISA) is based on the Local Moran $I_{i}$ statistics (Anselin 2006). This yields a measure of spatial autocorrelation for each individual location, of the unit's tendency to have an attribute value that is correlated with values in nearby areas. Global characteristics of spatial autocorrelation always represent one statistic characterising the total spatial autocorrelation, which can, in extreme cases, indicate clustering or a chess pattern. When calculating the statistics, we assume homogeneity. If this assumption is not met, the use of just one global statistic for the whole observed territory is senseless, as the statistic may change in space. It could happen that there is not a proven global spatial autocorrelation or clustering in particular data, and could still be possible to find clusters in some areas. Then it is suitable local statistics which are bounded to a particular place. Local indicators of the spatial autocorrelation are usually denoted, in scientific papers, by LISA (see, for example, Fotheringham and Rogerson 2009). LISA statistics serve, according to Anselin (2010), two purposes: on the one hand, it is possible to interpret them as indicators of local foci of non-stationary or "problematic" places (so-called hot and cold spots); on the other hand, it is possible to use them for the assessment of the influence of particular locations on global statistics and the identification of "outliers". Anselin (2010) defines local indicators of the spatial association LISA as a statistic which meets the following two requirements:

1. LISA indicates, for every location (observation), a range of significant spatial clustering of similar values around this location;

2. The sum of LISA values is, for all observations, proportional to the global indicator spatial association value.

$$
\text { Local Moran's I: } I_{i}=\frac{z_{i}}{m_{2}} \sum_{j} w_{i j} z_{j},
$$

where $z_{i}$ are values of the observed variable, $w_{i j}$ are the so-called spatial weights expressing the influence of the location of particular municipalities, and $m_{2}=\sum_{i} z_{i}^{2}$ does not change with $i$; therefore, it is true that $\sum_{i} I_{i}=n \cdot I, I=\frac{1}{n} \sum_{i} I_{i}$. In other words, making the average of the local $I_{i}$, we obtain global $I$. 
Statistical analyses were performed in Statistica and GeoDA programs. While Statistica served for classical (non-spatial) statistical analysis (correlation and cluster analysis of variables, PCA, factor analysis), GeoDA was used for the testing of spatial autocorrelation and LISA. Results of LISA were then portrayed in ArcGIS in the form of maps.

\section{Results and Discussion}

\section{Definition of Suburban and Rural Municipalities}

In the model commuting zones, 1,322 municipalities of a suburban character were identified by a spatial query. The data were converted to the territorial structure of 2011. It is necessary to note, however, that the model is therefore a simplified expression of reality. The set of rural municipalities, defined as municipalities of up to 3,000 inhabitants outside the suburban area, is then composed of 4,561 municipalities, without military training areas of 4,557 municipalities. The rural area defined in such a way covers almost $65 \%$ of the Czech Republic.

\section{Typology of Rural Municipalities}

Factor analysis of individual clusters of variables and spatial statistics of factors

Only chosen factors and their spatial patterns are described in this part due to the limited extent of the contribution.

In the first cluster of variables (importance and size of the municipality), the factor analysis identified three factors that explain $71.3 \%$ of the total variability. The first factor can be simply described as a variable expressing the "size of the municipality" (which explains $37.4 \%$ of variability), and (positively) loads heavily on variables O2011, CAST11 and HA. The second weaker factor explains $19.2 \%$ of variability and (positively) loads mainly on variables ZAST11r, hustota11 and KANAL11r. It can, therefore, with a certain degree of generalisation, be described as a variable expressing "built-up areas". The third factor explains $14.7 \%$ of the total variability and (positively) loads on variables UBYT11r and HUZ11. It thus describes 
"selected services" in the territory. Table 1 contains the factor loadings for the first category of variables.

Table 1. Factor loadings for the category of variables depicting the importance and size of municipalities

\begin{tabular}{|c|c|c|c|}
\hline \multirow{2}{*}{ Variable } & \multicolumn{3}{|c|}{ Factor } \\
\cline { 2 - 4 } & Size & Built-up area & Selected services \\
\hline CAST111 & 0.888 & & 0.237 \\
\hline HA & 0.867 & & \\
\hline O2011 & 0.687 & 0.453 & 0.172 \\
\hline hustota11 & 0.225 & 0.853 & 0.922 \\
\hline ZAST & & 0.836 & 0.712 \\
\hline KANAL11 & & 0.595 & \\
\hline UBYT11 & & & \\
\hline HUZ11 & 0.422 & 0.171 & \\
\hline
\end{tabular}

Source: CSO, own results in Statistica

LISA allows us to identify, with the Local Moran $I$, statistically significant spatial clusters of high and low values (hot spots) of the factor, along with the spatial outliers, when the hot spots occur next to the cold spots, and vice versa. It can be shown on the factors in cluster 2 . The number of variables in cluster 2 (municipality development) was reduced to two main factors explaining $67.2 \%$ of the total variability. The first factor (explaining $50.1 \%$ of variability) mostly correlates (positively) with variables D01_11, chpMS01_11 and IO01_11; the second factor explains $17.1 \%$ of variability and variables IVZD11, OZC11r and BDINT11r contribute (positively) to it. The first factor can be cautiously described as a variable expressing "growth". The second factor can be described as a variable expressing the "progressivity" of the municipality. Table 2 contains the factor loadings of the individual variables.

Growth factor (see Figure 1) defines the areas with high values of this component in the hinterland of large cities, which is not surprising when considering the fact that all municipalities (except for Prague and military areas) are evaluated in an attempt to carry out a typology of rural communities 
and their inclusion in the whole settlement system. Spatially less extensive clusters of municipalities appear in the hinterland of other towns in which there is economic development of different activities (Česká Třebová, Domažlice, Náchod, and more).

Table 2. Factor loadings for the variables group describing community development

\begin{tabular}{|c|c|c|}
\hline \multirow{2}{*}{ Variable } & \multicolumn{2}{|c|}{ Factor } \\
\cline { 2 - 3 } & Growth & Progressivity \\
\hline IO01_11 & 0.913 & 0.133 \\
\hline chpMS01_11 & 0.908 & 0.145 \\
\hline D01_11 & 0.733 & 0.409 \\
\hline BDINT11r & 0.219 & 0.783 \\
\hline IVZD11 & 0.367 & 0.774 \\
\hline OZC11r & & 0.754 \\
\hline ZMC11r & 0.293 & 0.440 \\
\hline
\end{tabular}

Source: CSO, own processing in Statistica.

Identified clusters must be evaluated with regard to variables that contribute largely to this factor (the development of population in the years 2001-2011, the share of houses built or renovated in the years 2001-2011, and chronological average net migration during the same period). The population size in this group of municipalities increased by $16 \%$ on average during this period.

The average value of chronological average net migration is 11 per 1,000 . It is also an above-average proportion of houses built or reconstructed in that decade (14\%). With regard to the information available in literature, it is somewhat surprising that a large part of Moravia, particularly the Ostrava region, belongs to the hot spots of this factor, although it is a known fact that North Moravia, in the long term, loses the size of population by migration in favour of (central) Bohemia (see, for example, Vobecká 2009).

The results may be affected by the assessed period, the variables used, and, of course, a statistical method. Cold spots of the growth factor are located mostly on the territory of three regions: the Vysočina region, the South Bohemian region, and the Plzen region (excluding the Plzeň hinterland), 
mainly in peripheral areas. The part of these spots is situated along the regions' border, thus affirming the existence of the internal peripheries.

Figure 1. LISA of the factor describing municipality growth

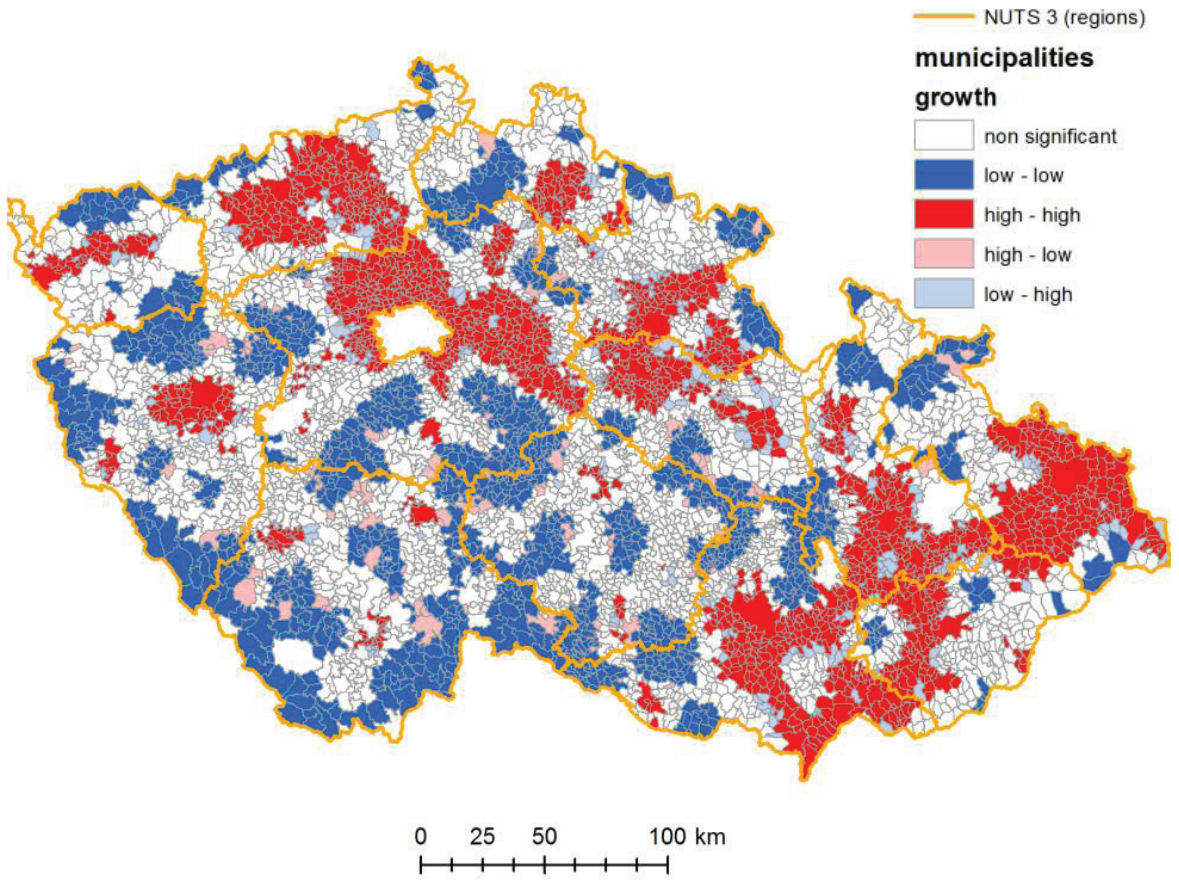

Sources: CSO, digital geographic database ArcCR500 - own processing in ArcGIS and GeoDA.

The factor specified provisionally as "progressivity", which largely loads a share of the households connected to the Internet (BDINT11r), the index of education (IVZD11), and the proportion of employed population to the total number of economically active population (OZC11r), again logically produces (in accordance with the evaluation of rural communities throughout the whole settlement system) hot spots in the hinterland of regional cities, which is related to the process of suburbanisation, and with related specifics of municipalities in suburban areas where there are higher rates of Internet connection (higher than 50\%) and higher levels of education and employment rates. 
The progressivity factor reaches statistically low values of this component mainly along some regions' border regions, known as the inner periphery. It is possible to assume that the lower shares of the indicators which largely load the factor of progressivity in these municipalities are related to the ongoing demographic ageing, insufficient service availability, and inadequate transport services of these municipalities. Figure 2 illustrates the results of LISA concerning the factor of progressivity.

Figure 2. LISA of the factor describing municipality progressivity

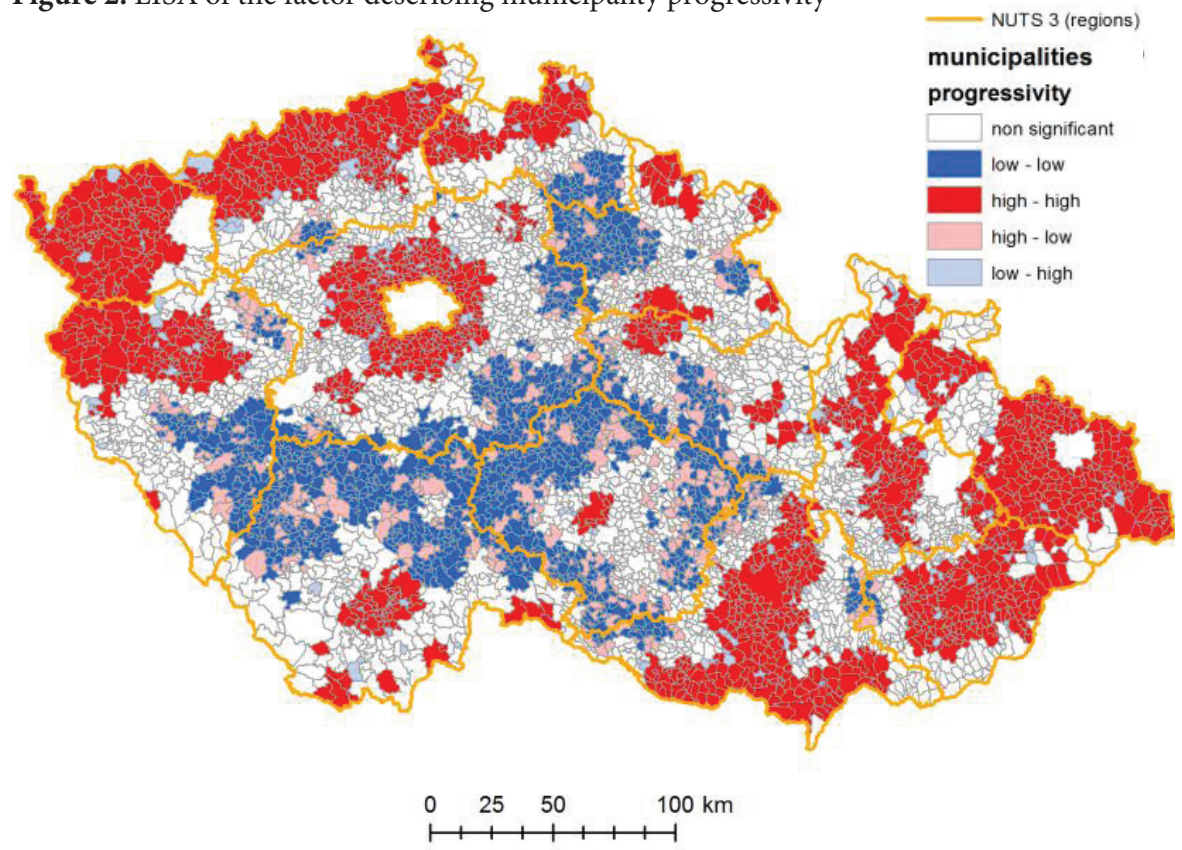

Sources: CSO, digital geographic database ArcCR500 - own processing in ArcGIS and GeoDA.

Cluster 3 (potential for economic and leisure activities) was reduced, by factor analysis, to two factors. These two factors generally explain $53.1 \%$ of the total variability. The first factor (explaining $29.3 \%$ of variability) is largely correlated with variables describing the location of the municipality, and the second one with variables IEZ11, IS11 and NEOBD11r. The first factor can therefore be described provisionally as a variable expressing the "location" of the municipality, and the second one illustrates the municipalities "ageing" 
with its consequences. Table 3 contains the factor loadings of the individual variables.

Table 3. Factor loadings for the category of variables describing the potential for economic and leisure activities development in the municipalities

\begin{tabular}{|c|c|c|}
\hline \multirow{2}{*}{ Variable } & \multicolumn{2}{|c|}{ Factor } \\
\cline { 2 - 3 } & Location & Ageing \\
\hline NEARORP & 0.678 & 0.134 \\
\hline NEARSIL & 0.635 & \\
\hline NEARZS & 0.624 & 0.174 \\
\hline VODYLESY11r & 0.509 & 0.452 \\
\hline DREKR11r & 0.495 & 0.735 \\
\hline IEZ11 & -0.125 & 0.688 \\
\hline IS11 & & 0.602 \\
\hline NEOBD11r & 0.550 & 0.486 \\
\hline PRIM11r & 0.403 & \\
\hline
\end{tabular}

Source: CSO, own processing in Statistica.

The fourth cluster of variables (social stability and employment) can be reduced by factor analysis into three factors that explain $76.4 \%$ of the total variability. The first factor explains $39.4 \%$ of variability and it largely loads on variables VYJdmo11r, RD11r and MANZ11r - it can be provisionally described as the factor "family". The second one (explaining 20.2\% of variability) mainly loads on variables NAROB11r and VIRA11r - it can therefore be described as the factor of stability. The third factor - especially correlated with the variable ZAMST11r - shows $16.8 \%$ of the total file variability. The third factor can be described as the "employment" factor. Table 4 contains the factor loadings of the individual variables.

The "stability" factor gives predictable results after the assessment by LISA tools. Owing to variables which are loaded on this factor, there is quite an expectable gradient in the NW-SE direction. Moravian and Vysočina region municipalities are characterised by high shares of natives and religion, whereas in the north part of Bohemia, society is far more secularised with 
lower shares of natives. Of course, different historical development and character of the settlement have become evident.

Table 4. Factor loadings for the category of variables describing social stability and municipality employment

\begin{tabular}{|c|c|c|c|}
\hline \multirow{2}{*}{ Variable } & \multicolumn{3}{|c|}{ Factor } \\
\cline { 2 - 4 } & Families & Stability & Employment \\
\hline RD11r & 0.799 & 0.191 & \\
\hline MANZ11r & 0.753 & 0.154 & -0.125 \\
\hline VYJdmo11r & 0.726 & & 0.477 \\
\hline NAROB11r & 0.116 & 0.901 & 0.128 \\
\hline VIRA11r & 0.190 & 0.873 & 0.936 \\
\hline ZAMST11r & & 0.153 & \\
\hline
\end{tabular}

Source: CSO, own processing in Statistica.

Despite the fact that roughly half of the Czechs did not comment on the question of religion in the last census, the spatial distribution of the shares of believers has not changed a lot since the period of the 2001 Census. With reference to the shift in regional policies towards endogenous sources of developmental potential of municipalities, this factor has been considerably important.

Figure 3 illustrates the results of the factor stability by LISA. This factor is directly related to the concept of social capital, where it is assumed that some form of social organisation and social behaviour have a more positive impact on the development of localities and regions than others. Šafr and Sedláčková (2006) and Majerová et al. (2011) deal with the theory of social capital and its measurement methods, along with its relevance to local and regional development. From the existing research on the polarisation of the Czech Republic, or its peripheries (Jančák 2001; Novotná 2005), it is obvious that for the development of peripheries the position in the settlement hierarchy remains determining, along with the weakening importance of the economic aspects of their development. Greater importance is attached to the social and cultural aspects, or to the quality of human and social capital in this area (Jančák et al. 2010). 
Figure 3. LISA of the factor labelled "stability"

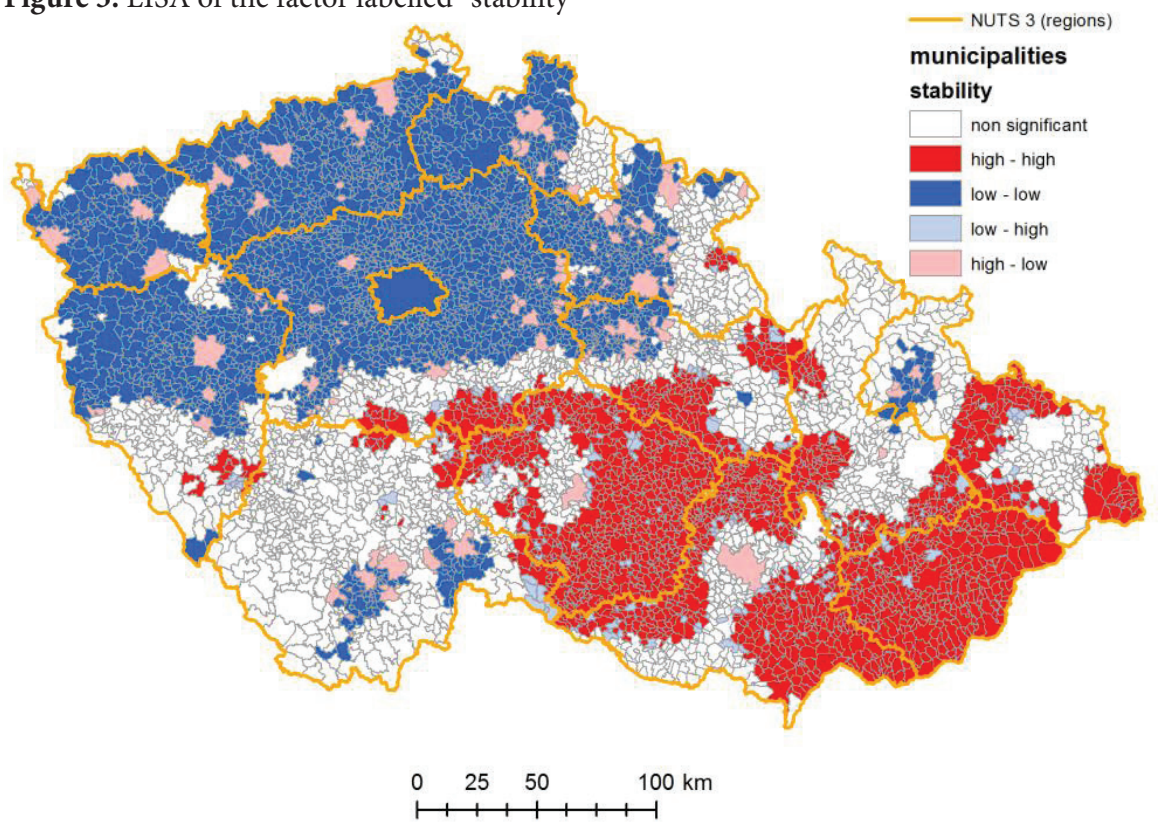

Source: CSO, digital geographic database ArcCR 500 - own processing in ArcGIS and GeoDA.

\section{Cluster Analysis of Factors}

The original set of 29 variables, somewhat characterising partial aspects of the potential of development of individual municipalities, was reduced to 10 factors. Regarding the fact that the above-mentioned factors were obtained from four independent analyses, we can assume that they are correlated. Bivariate correlations of individual factors are relatively small; therefore, a cluster analysis can be used. For a specific typology of (rural) municipalities a cluster analysis was then used. It was carried out by the k-means method (Harris 2001). Testing of the different number of clusters, taken into consideration on the basis of a dendrogram within previous hierarchic clustering, finally resulted in a decision to divide the municipalities placed in a rural category into seven clusters.

In all cases the factors used for clustering were statistically significant for the splitting of municipalities into clusters (see Table 5). Regarding the fact 
that it is impossible to assess the country without relating it to towns, and that the border between them is not sharp, the final typology includes all municipalities, regardless of their placing in a category, except for Prague and military domains. Within the cluster analysis of rural municipalities, two not numerous clusters based on a similarity of values of individual factors were joined with the most similar clusters with a higher frequency. Thus, we obtained seven types of municipalities, six of which are represented by nonurban municipalities (rural and suburban). The final clusters are illustrated in Figure 4. Results are naturally influenced by the selection of variables and methods used.

The first cluster represents 884 municipalities smaller in population but larger in size and with worse accessibility, which are situated prevailingly in the border areas of South Bohemia, in Western Bohemia, and in the Jeseníky area. Compared with the other clusters, municipalities in this group characterise a relatively favourable age structure, the lowest education rate, low shares of religious people, the lowest share of people living in marriage, and a lower share of natives.

Table 5. Cluster analysis of factors - ANOVA

\begin{tabular}{|c|c|c|c|c|c|c|}
\hline \multirow{2}{*}{ Factor } & \multicolumn{2}{|c|}{ Cluster } & \multicolumn{2}{c|}{ Error } & \multirow{2}{*}{ F } & \multirow{2}{*}{ Sig. } \\
\cline { 2 - 6 } & Mean square & df & Mean square & df & & \\
\cline { 2 - 6 } & & & & & & \\
\hline F11 & 429.735 & 6 & 0.408 & 4.554 & $1,054.326$ & 0.000 \\
\hline F12 & 14.396 & 6 & 0.347 & 4.554 & 41.462 & 0.000 \\
\hline F13 & 205.252 & 6 & 0.688 & 4.554 & 298.118 & 0.000 \\
\hline F21 & 397.439 & 6 & 0.442 & 4.554 & 898.839 & 0.000 \\
\hline F22 & 544.648 & 6 & 0.408 & 4.554 & $1,334.737$ & 0.000 \\
\hline F31 & 397.439 & 6 & 0.442 & 4.554 & 898.839 & 0.000 \\
\hline F41 & 544.648 & 6 & 0.408 & 4.554 & $1,334.737$ & 0.000 \\
\hline F42 & 144.412 & 6 & 0.582 & 4.554 & 248.338 & 0.000 \\
\hline F43 & 144.447 & 6 & 0.772 & 4.554 & 187.007 & 0.000 \\
\hline
\end{tabular}

Source: CSO, author's own research in Statistica.

These are areas with an intense population exchange in the past, which negatively influenced both social stability and human capital. Basic service 
facilities and technical infrastructure in this cluster can be marked as below average. Population growth in the last decade, together with a favourable share of areas suitable for recreation but not fully used thus far by mass forms of tourism, as well as a relatively favourable age structure, implies a capacity for further development (with properly chosen tools of regional development). However, a certain handicap is that of the low education rate and low share of employers. After long consideration, the cluster was marked as a "non-profile country".

The second cluster is formed by 840 municipalities small in population and size, with a very high old-age index and a relating highest value of index of economic burden. Compared with the other clusters, it also shows a high share of commuters for jobs outside their home and a high share of people employed in agriculture, forestry and fishing. In this cluster, a considerable proportion of houses are used for recreation. Municipalities in this group also show high values of chronological average of net migration during the period 2001-2012, which could indicate, for example, a shift in using certain houses from recreation to permanent residence or, for example, some manifestations of amenity migration. In this cluster we also recorded the lowest building activity for both 1991-2001 and 2001-2011. It also shows the lowest share of people employed in selected branches of services (accommodation and catering), the lowest number of mass accommodation facilities, the lowest share of homes with access to the Internet, and the worst basic service facilities as well as technical infrastructure of all clusters. Therefore, it was determined as a "problem recreational countryside". This type of municipality exists almost exclusively in the Czech part.

The third group of municipalities is formed by 55 border municipalities, which are medium-sized in population, but large in area, and with a high number of mass accommodation facilities, a high share of people employed in accommodation and catering branches, a low proportion of employees to employed people, and, vice versa, a high share of employers, which proves an intensive use of these areas not only by mass forms of tourism, but also for individual recreation. This testifies to the highest share of non-inhabited houses and a high share of houses used for recreation. This cluster shows the lowest proportion of commuters, which implies that people find jobs in their home area. It concerns especially areas used intensively for tourism in parts of the Šumava, the Giant Mountains, Czech Switzerland, the Eagle Mountains, and the Ash Mountains. 
For this cluster, the lowest proportion of natives and houses is typical. During the periods 1991-2001 and 2001-2011 the highest intensity of building was recorded here. It is connected also with very good public facilities and technical infrastructure. A high value of the Education Index is also typical. Future development should be considered and planned with the intention of sustainability and prospective elimination of possible negative impacts of one-sided, intensive use of tourism. The cluster was determined a "border countryside intensively used by tourism".

Another type of countryside is formed by 1,948 municipalities, bigger in population, characterised by a high density of population, built-up areas, and a relatively favourable age structure. These municipalities are situated in the Moravian part of the state, in the Vysočina region and Pardubice region. These are municipalities with the largest proportion of employees to employed people, average proportions of employers, the lowest proportion of employees in primary branches, and also the highest number of commuters having jobs outside their place of residence. For municipalities of this cluster, they are typical for above-average proportions of natives, religious people, and people living in marriage, which implies social stability. This group also showed mass building during the period 1991-2011 as well as population growth (by $7 \%$ on average) and migration gains. The cluster shows the lowest proportion of non-inhabited houses and houses used for recreation. From the viewpoint of homes connected to the Internet, public facilities, and a basic technical infrastructure, the group determined as being equipped is above average. The cluster was determined a "stable developing countryside".

The last cluster, determined a "stable non-developing countryside", is formed by 823 municipalities smaller in population, but larger in area and with a low built-up area, situated prevailingly near borders of certain Czech regions, thus being in poor reach, i.e. corresponding, to a certain extent, to the so-called internal outskirts. This cluster shows the highest employment rate in the primary sector, as well as the highest proportion of natives, religious people, and people living in marriage, which implies social stability. Furthermore, migration gains are small, which is connected with population size stagnation. Related to this are a less favourable age structure and a high index of economic burden. A higher share of non-inhabited houses and houses used for recreation proves the usage of part of housing stock for individual recreation. Non-development of this group is indicative also of basic service facilities and technical infrastructure being below average. 
Figure 4. Typology of municipalities of the C.R. according to their development potential

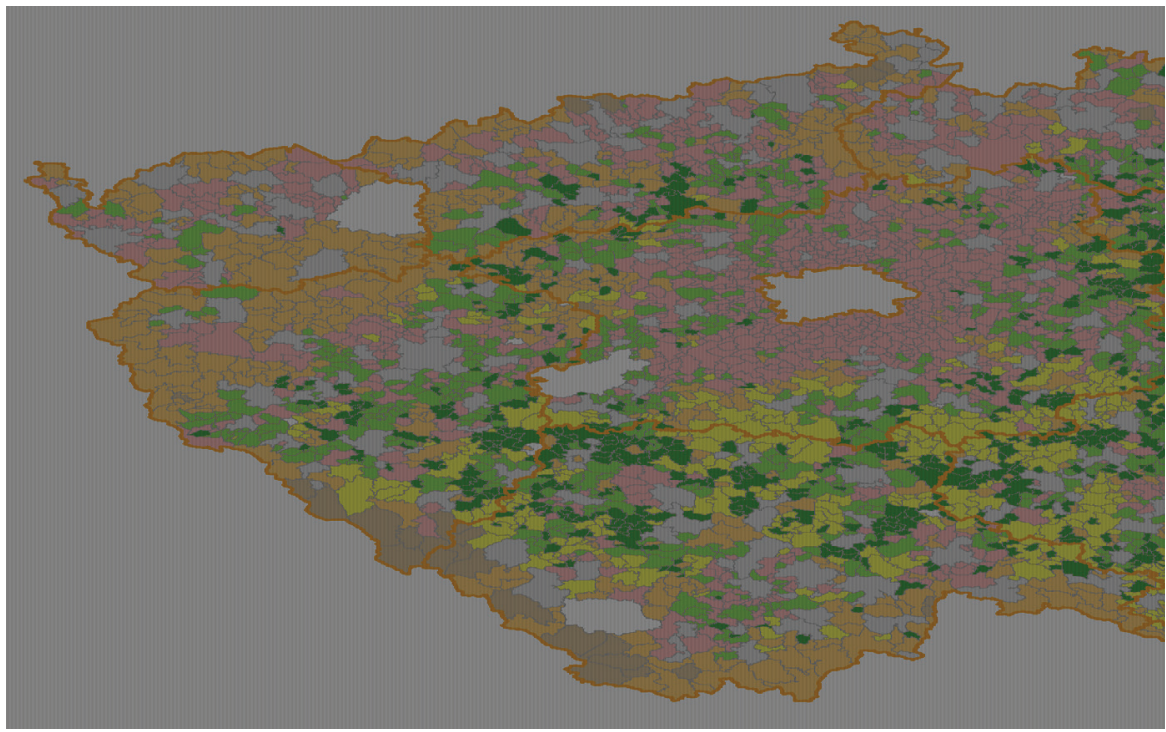

Sources: CSO, ArcČR 500 - author’s own research in Statistica and ArcGIS.

\section{Conclusions}

The accomplished typology of rural municipalities from the viewpoint of their development potential confirmed the assumption of significance of the size and geographical position for differentiation of rural municipalities in the Czech Republic (see also Perlín et al. 2010). The significance of these factors has been described in literature frequently (e.g. Hampl 2005). The factor of size, which is expressed as a combination of the size of population, the extent of registered land area, and the number of parts, proved significantly the differentiation of all types of rural municipalities. The most numerous type - "stable developing countryside" - is represented by municipalities bigger in population, with an average extent of registered land area, a high density, and built-up areas, which are typical, especially for Moravia. In the Czech countryside, municipalities small in population dominate with different extents of their registered land areas and a number of parts: the "problem recreation countryside" affected by intensive demographic ageing, a "stable non-developing countryside" in outskirts positions, and 
a "non-profile countryside". On determining particular types of countryside areas, a remaining dichotomy between border areas inhabited after WW2 and inland appears in some characteristics; this is reflected especially in indices expressing the quality of social and human capital. Changes in socioeconomic conditions, especially after 1989, further proved the development of core areas through a differentiation of countryside municipalities given by their position towards the centres of growth. Thus, a significant group of suburban municipalities have been profiled, showing considerable changes in building character and, in particular, the way of life, which is considerably drawing near the urban style. Apart from the factor of position, an important role is also played by the factor of growth.

A countryside is a complicatedly structured system, both spatially and socially. Generally, the possibilities of a countryside unfold from internal sources and external impacts and trends; nevertheless, using chances from the scale of opportunities, a choice of developing tools is given by practicably existing and working developmental structures. Key and mutually inseparable steps are the knowledge of a rural region, creation of a system of connections and relations of partakers of development, and coordination of developmental activities of particular subjects. Gaining this knowledge can be supported by the above-mentioned typology of rural municipalities. However, it cannot be understood only as a single and universal source of knowing the rural.

Apart from the typology based on the statistic processing of "hard" figures, it is also necessary to study "soft" factors which are certified by a number of studies of rural areas in accordance with a changing paradigm of rural development. A real revival of the countryside consists especially in its inhabitants and their activities and entrepreneurship, in the abilities and enthusiasm of municipal authorities, and in the common effort of all subjects of a country - citizens, non-profit sector, entrepreneurs, municipal representatives, and all others cooperating on the development of a given area. However, we cannot neglect external impacts: legislative amendments eliminating useless organisational and legal barriers which are perceptible, especially in smaller municipalities; the financial support necessary at least in the first stage of developmental trajectory, when identification and development of local sources appear; information and technical aid provided by the region and state; and further measures and activities. 
The combination of classical statistical methods and GIS tools and spatial statistics allows also the identification of a spatial pattern of the used factors. It could be perceived as a shift from the methodological point of view.

\section{References}

Ambrosio-Albalá, M. and Bastiaensen, J., 2010. The new territorial paradigm of rural development: Theoretical foundations from systems and institutional theories. Institute of Development Policy and Management, Discussion Paper, University of Antwerp, Antwerp, http://www.ua.ac.be/objs/00251118.pdf (6. 4. 2012).

Anselin, L. 2006. GeoDA: An Introduction to Spatial Analysis. Geographical Analysis, 38(1), pp. 5-22. Available at: http://dx.doi.org/10.1111/j.0016-7363.2005.00671.x.

Anselin, L., 2010. Local Indicators of Spatial Association - LISA. Geographical Analysis, 27(2), pp. 93-115. Available at: http://dx.doi.org/10.1111/j.1538-4632.1995. tb00338.x.

Daskalopoulou, I., Hassapoyannes, K.\& Petrou, N., 1998. An introduction to different conceptualisations of endogenous rural development. In: Stamataki, E., Clapan, C. (eds.): Endogenous rural development in the Mediterranean region. Chania. CIHEAM, 1998, Cahiers Options Méditerranéennes; (30), pp. 1-9.

Ellis, F., Biggs, S., 2001. Evolving Themes in Rural Development 1950s-2000s. Development Policy Review, 19 (4), pp: 437-448. Available at: http://dx.doi. org/10.1111/1467-7679.00143

Evans, N., 2009. Adjustment strategies revisited: Agricultural change in the Welsh Marches. Journal of Rural Studies, 25(2): 217-230. Available at: http://dx.doi. org/10.1016/j.jrurstud.2008.10.002.

Fotheringham, A., S., Rogerson, P., A., 2009. The SAGE Handbook of Spatial Analysis. SAGE Publications, London. Available at: http://dx.doi.org/ $10.4135 / 9780857020130$.

Garrod, B., Wornell, R., Younell, R., 2006. Re-conceptualising rural resources as countryside capital: The case of rural tourism. Journal of Rural Studies, 22(1): 117128. Available at: http://dx.doi.org/10.1016/j.jrurstud.2005.08.001

Hampl, M., 1998. Realita, společnost a geografická organizace: hledání integrálního řádu [The reality, society and geographic organization: the search for integral order]. DemoArt, Praha, $110 \mathrm{p}$.

Hampl, M., 2005. Geografická organizace společnosti v České republice: transformační procesy a jejich obecný kontext [Geographical organization of society in the Czech Republic: transformation processes and their general context]. Univerzita Karlova v Praze, Př́rodovědecká fakulta, katedra sociální geografie a regionálního rozvoje, Praha, $145 \mathrm{p}$. 
Harris, M., J., 2001. A Primer of Multivariate Statistics. Lawrence Erlbaum Associates, Publishers, London, 609 p. Available at: http://dx.doi.org/10.4324/9781410600455.

Hebák, P., Hustopecký, J., Jarošová, E., Pecáková, I., 2005. Vícerozměrné statistické metody 3 [Multivariate Statistic Methods 3]. Informatorium, Praha, 256 p.

Jančák, V., 2001. Příspěvek ke geografickému výzkumu periferních oblastí na mikroregionální úrovni [Contribution to the geographical research on peripheral regions at the microregional level]. Geografie, 106, 1, pp. 26-35.

Jančák, V., Chromý, P., Marada, M., Havlíček, T. \& Vondráčková, P. , 2010. Sociální kapitál jako faktor rozvoje periferních oblastí: analýza vybraných složek sociálního kapitálu v typově odlišných periferiích Česka [Social capital as a factor in the development of peripheral areas: an analysis of selected components of social capital in Czechia's typolgically different peripheries]. Geografie, 115, 2, pp. 207 222.

Jenkins, T., N., 2000. Putting postmodernity into practice: endogenous development and the role of traditional cultures in the rural development of marginal regions. Ecological Economics, 34, pp. 301-313. Available at: http://dx.doi.org/10.1016/ s0921-8009(00)00191-9.

Kubeš, J., 2000. Problémy stabilizace venkovského osídleníČR [Problems of stabilization of rural settlement in the Czech Republic]. Jihočeská univerzita v Č. Budějovicích, Pedagogická fakulta, Katedra geografie, Č. Budějovice, 164 p.

Lee, J., Árnason, A., Nightingale, A. \&Shucksmith, M., 2005. Networking: Social Capital and Identities in European Rural Development. Sociologia Ruralis, 45(4), pp. 269-283. Avaiable at: http://dx.doi.org/10.1111/j.1467-9523.2005.00305.x.

Majerová, V., Kostelecký, T. \& Sýkora, L., 2011. Sociální kapitál a rozvoj regionu. Př́klad Kraje Vysočina [Social Capital and Regional Development: District Vysočina Example], Grada, Praha, 224 p.

Marsden, T., Sonnino, R., 2008. Rural development and the regional state: Denying multifunctional agriculture in the UK. Journal of Rural Studies, 24(4), pp. 422-431. Available at: http://dx.doi.org/10.1016/j.jrurstud.2008.04.001.

Musil, J., Müller, J., 2006. Vnitřní periferie České republiky, sociální soudržnost a sociální vyloučení [Inner Peripheries of the Czech Republic, Social Cohesion and Social Exclusion]. CESES FSV UK, Praha, Avaliable at: http://ceses.cuni.cz/ CESES-20-version1-s06_02.pdf (8. 9. 2013).

Novotná, M., 2000. Hodnocení zemědělského využívání krajiny v pohraničním regionu Pošumaví [Evaluation of agricultural land use in the border region Pošumaví]. Geografie, 105, No. 1, pp. 34-49.

Novotná, M., 2005. Problémy periferních oblastí [Problems of peripheral areas]. Univerzita Karlova v Praze, Př́rodovědecká fakulta, Praha, 184 p. Available at: http://www.periphery.cz/download/nectiny.pdf (10.10. 2015).

OECD, 2006. The New Rural Paradigm: Policies and Governance. OECD, Paris. Available at: http://dx.doi.org/10.1787/9789264023918-en. 
Ouředníček, M., Špačková, P. \& Novák, J., 2013a. Metodika sledování rozsahu rezidenční suburbanizace $v$ České republice (verze 3) [The method of monitoring the extent of residential suburbanization in Czechia (version 2)]. Univerzita Karlova v Praze, Př́rodovědecká fakulta, Katedra sociální geografie a regionálního rozvoje, Urbánní a regionální laboratoř, Praha. Available at:

http://www.suburbanizace.cz/odborne/25_MetodikaRS_3verze.pdf (28. 12. 2013).

Ouředníček, M., Špačková, P., Novák, J., 2013b. Sub urbs: krajina, sídla a lidé [Sub Urbs: Landscape, Settlements and People]. Academia, Praha, 200 p.

Perlín, R., Kuldová Š., 2008. Typology of rural areas. In: Majerová, V. (ed.): Sborník příspěvků z mezinárodní vědecké konference Venkov je náš svět, Countryside Our World, ČZU, Praha, pp. 445-455.

Perlín, R., Kučerová, S., Kučera, Z., 2010. Typologie venkovského prostoru Česka [A Typology of Rural Space in Czechia according to its Potential for Development]. Geografie, 115(2), pp. 161-187.

Perlín, R., 2013. Vymezení venkova [Rural Delimitation]. Seminář Výzkumného centra RURAL, Př́rodovědecká fakulta UK, available at: http://geography.cz/ wp-content/uploads/2013/02/Perl\%C3\%ADn-vymezen\%C3\%AD-venkova-propot\%C5\%99eby-PRV.pdf (15. 3. 2013).

Short, J. R., 1991. Imagined country: society, culture and environment. Routledge, London, $253 \mathrm{p}$.

Strategie regionálního rozvoje ČR 2014 - 2020 [Regional Development Strategy of the Czech Republic 2014-2020]. MMR ČR, Praha, 2013. Available at :http://www. mmr.cz/getmedia/08e2e8d8-4c18-4e15-a7e2-0fa481336016/SRR-2014-2020.pdf (24. 6. 2013).

Šafr, J., Sedláčková, M., 2006. Sociální kapitál: koncepty, teorie a metody měrení [Social Capital: Concepts, Theory and Methods of Measure]. Sociologický ústav Akademie věd České republiky, Praha, 93 p.

Terluin, I., 2001. Rural regions in the EU. Rijksuniversiteit Groningen, Groningen, http://dissertations.ub.rug.nl/faculties/rw/2001/i.j.terluin/ (21. 12. 2012).

Vobecká, J., 2009. Dojíždlkový přístup k vymezení městského, příměstského a venkovského obyvatelstva v České republice [The Commuting Approach to Delimiting Urban, Suburban, and Rural Populations in the Czech Republic]. Demografie, 51, No. 1, pp. 14-23.

Woods, M., 2011. Rural. Routledge, London, 336 p. 